SHS Web of Conferences 23, 01004 (2016)

DOI: $10.1051 /$ shsconf $/ 20162301004$

(C) Owned by the authors, published by EDP Sciences, 2016

\title{
The Ornamental Design of Traditional Malay Utensils (Kukuran) in Peninsula Malaysia
}

\author{
Zulkfli bin Md Yusoff ${ }^{1}$, Dzul Haimi bin Md Zain ${ }^{2}$ and Hamidon bin Saniman ${ }^{3}$ \\ ${ }^{13}$ Visual Communication and Design Department, Politeknik Ibrahim Sultan, Johore \\ ${ }^{2}$ Faculty of Art and Design, Universiti Teknologi MARA, Selangor
}

E-mail: aiman_zulkifli@yahoo.com

\begin{abstract}
Woodcarving is a significant craft in Malay society that reflects the local traditions and customs. It is a manifestation of craftsmen artistic skills and intutitive ideas into a piece of wood. It is also manifestation of the creative process of imitation, denaturalization, stylization and abstraction. Historically, the Malay craftsmen have created many attractive traditional art forms and one of it is the coconut graters (kukuran). The ornamental carved kukuran is closely related to its Malay woodcarving tradition and philosophy. The aim of this paper is to illustrate this tradition of the great traditional Malay kukuran, the testiment of its time through its visual characteristics and design composition. This study presents an analysis of six kukuran, which were gathered from the state museums in Peninsular Malaysia. The discussion is focused on the formalistic and iconology aspects of the kukuran carving ornaments. The finding briefly shows the fusion of Malay concept of beauty, Malay culture and the understanding of Islam had been manifested in these domestic utensils - the ornamental kukuran.
\end{abstract}

Keywords: woodcarving, ornamental carved, motifs, coconut grater (kukuran)

\subsection{INTRODUCTION}

The art of carving has been practised by Malays since the ancient time. This art was closely devoted with the sculpture in the Megalithic culture (Abdul Halim Nasir, 1987). A collection of Megalithic stones in Pengkalan Kempas, prehistoric rock painting at Gua Tambun and also a collection of ancient monument and artefacts had illustrated that Malays appreciated the art of sculpture and carving. However, the earliest evidence on woodcarving is in Malay literature, the Malay Annals (Sejarah Melayu). It describes the palace of "Lust and Desire" (Istana Hawa Nafsu) Sultan Mansur Shah of Melaka (1459-1477) was fully decorated with woodcarvings (Abdul Halim Nasir, 1987; Wan Hashim Wan The, 1996). Raja Chulan has written in Misa Melayu, mentioned the utilization of woodcarvings to decorate the palace of Sultan Iskandar Zulkarnain (1756-1780). Today, the remaining carved wooden buildings are Istana Balai Besar of Kelantan, Istana Tengku Nik of Terengganu, Istana Raja Besut of Terengganu Istana Tengku Long of Terengganu, Istana Kota Raja of Terengganu, Istana Satu in Museum Negara, and Istana Sri Menanti of Negeri Sembilan (Abdul Halim 
Nasir, 1987; Syed Ahmad Jamal, 1994; Wan Hashim Wan Teh, 1996; Farish A. Noor \& Khoo, E., 2003).

Malay woodcarvings mainly emphasized on the traditional architecture and traditional arts. Traditional architecture comprises of palaces, mosques, timber houses, household furniture and carved components. However, carvings are also available in utensils for daily use such as kitchen utensils, hilts of weapons, entertainment and ceremony equipments, fishery components and farming tools (Abdul Halim Nasir, 1987; Syed Ahmad Jamal, 1994; Seminar Report, 2005). It shows an expression of Malay craftsmen in manifesting ideas of beauty into a piece of wood. The level of artistry, creativity, style and identity had reflects the artistic of the Malay craftsmen. Syed Ahmad Jamal had stated that previous Malay craftsmen have created a traditional art form known as kukuran.

For centuries, kukuran (utilitarian product) is a necessity kitchen utensil in every Malay traditional lifestyle (Che Husna Azhari, 2011). Kukuran was a major kitchen appliance in every Malays traditional house, but sadly it perished due to the modern lifestyle. Syed Ahmad Jamal had classified kukuran as three dimensional artefacts. He had mentioned others three dimensional carving in Malay previous culture can be seen in the hilts of weapons such as kris, dagger (badik) and cleaver (parang), lecterns, headstones, congkak trays, embroidery frames and so forth. Mean while Rosnawati (2005) had delineate three dimensional carving or sculptural carving refers to the wooden tools used in Malay society. These include kitchen utensils, household furniture, fishery components and farming tools.

The study of the ornamental carved in kukuran is still a subject for deliberation, but significance in Malay woodcarving. The ornamental carvings in the body of kukuran evolved accordingly to the tastes and aesthetics preference of the previous Malay community. The ornamental carvings in kukuran were selected because they consist of various visual attributes including shapes, motifs, compositions, carving patterns, and carvings techniques. Thus, the ornamental carved in kukuran formed in three-dimensional carvings.

\subsection{THE CONCEPT OF BEAUTY IN MALAY WOODCARVING}

The Malay society is full of artistic elements and cultural affluence which reflect the sophisfication of the Malay civilization. The pre Islamic culture had long taken roots in the Malay society. However, elements in the art forms were progressively modified to conform to the Islamic values. Anything that is contrast with Islamic values was gradually discarded. Islamic influence in Malay society led the development in Malay woodcarving. The prohibition of figurative in the Islamic visual art has contributed to the other forms such as vegetal ornaments, arabesques surface patterns, and geometrical designs. The Islamic art sees geometry, exactness proportion, repetitive patterns, symmetry as the direct expression of the divine and God's perfect paradigm.

According to Abdullah Mohamed (known as Nakula, 1980), the concept of Divine Essence constitutes the foundation of Malay carving philosophy. He suggested two approaches which are "Ilmu al-Kalam" and "Ilmu Martabat Tujuh". He explained the concept of Divine Essence (Zat). This concept of Divine Essence (Zat) had been referred to the Jamal (beauty) and Jalal (magnificent). Therefore, he concluded that the term "source" or 
"seed" to describe the starting point of Malay woodcarving philosophy. The term sprout from origin or seed (tumbuh berpunca) symbolized a particular creation. It denoted that craftsmen were influenced by the devotion to the Creator of the Universe and concept of Divine Essence (Zat). Then, he had illustrated four types of woodcarving "source" were discovered in Tengku Sri Akar Raja palace (see Figure 1).

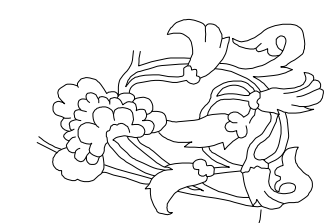

Close seed (benih tematuratpa)

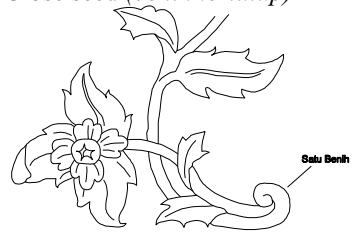

Real seed (benih nyata)

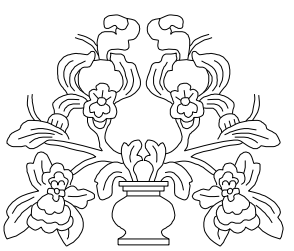

Seed like vase (benih berupa pasu)

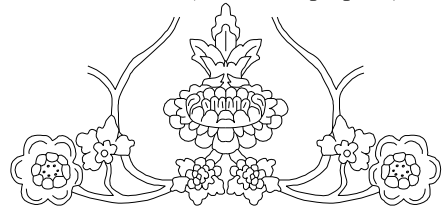

Seed like flower (benih berupa bunga)

Figure 1: Types of woodcarvings "origin or seed or source" by Nakula Illustrated by: Zulkfli bin Md Yusoff

Finally, Nakula constitutes the Ilmu-Hakikah into the "Sulur Kacang" carving as shown below (see Figure 2):

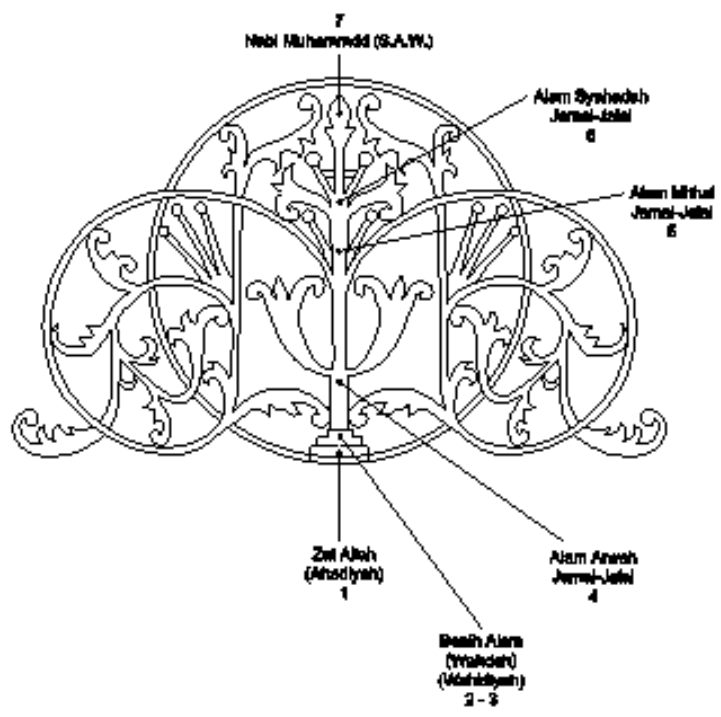

Figure 2: The complete application Ilmu-Hakikah in "Sulur Kacang" carving by Nakula Illustrated by: Zulkfli bin Md Yusoff

The beauty of art carving expressed by Wan Musa bin Wan Yusuf to Abdullah Mohamed (Nakula): "Tumbuh hendaklah berpunca, punca itu rahsia, tajam tidak menerjah lawan, lilit tidak memeluk lawan, tetapi berlegar mesra” (Balai Seni Lukis Negara, 2008). 
It was translated as: "It should sprout from an origin (seed); the origin is secret, sharp but not piercing neighbours, twisting but enfolding them, yet revolving intimately". The statement above reflected to the norm and custom in Malay community.

Zakaria Ali (1989) formulated Malay principles of beauty such as refinement (prinsip halus), usefulness (prinsip berguna), unity (prinsip bersatu), symbolism (prinsip berlambang), contradiction (prinsip berlawan) and meaningfulness (prinsip bermakna) in discussing traditional art objects. According to Syed Ahmad Jamal (1994), Malay woodcarving had integrated the elements of form, creativity, beauty, taste and culture. All these elements were considered and then transformation of nature to art that conforms to suitable motifs and patterns. It emphasizes on the aspects of beauty and norms in Malay culture. In the world of Malay woodcarving, the creative expressions of the woodcarvers were actually influenced by the act of total devotion to the Creator of the Universe (Syed Ahmad Jamal, 1994; Mohd Suhaimi Tohid, 2006).

\subsection{ORNAMENTAL CARVING MOTIFS}

The ornamental carvings on the body of the kukuran reflect the beauty, the creativity and skill of the Malays craftsmen in producing daily functional art form. Generally, the carving used in the kukuran can be classified into at least three different types which are flora, cosmos and simple geometric. The carvings for the kukuran looks simple but it actually portrays a high degree of creativity working on a limited space (see figure 3 ). The interesting here is the fusion of figurative shapes and vegetal motifs. The craftsmen were able to depict flora motifs within the animal form without any contradiction of composition. The conceptual, position and motifs used in its design are balance, repetitive, and harmony in arrangement.

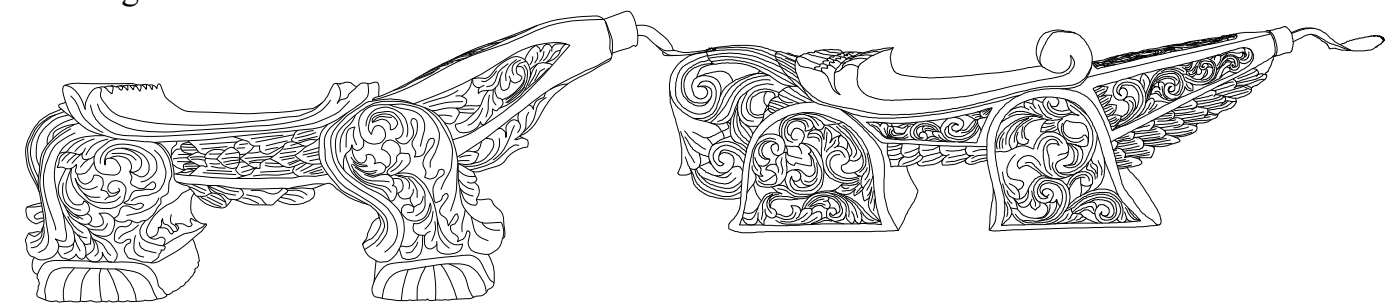

Source 1: Sultan Abu Bakar Museum, Pahang

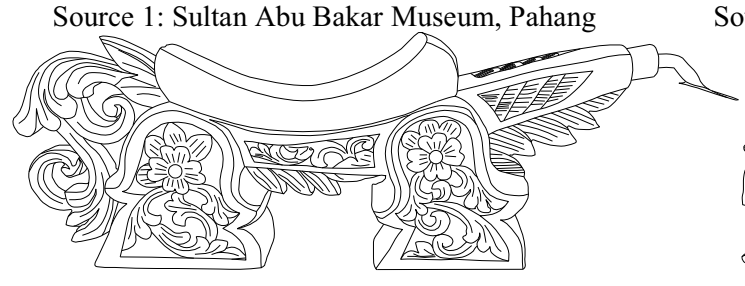

Source 3: Petaling Jaya Museum
Source 2: National Museum, Kuala Lumpur

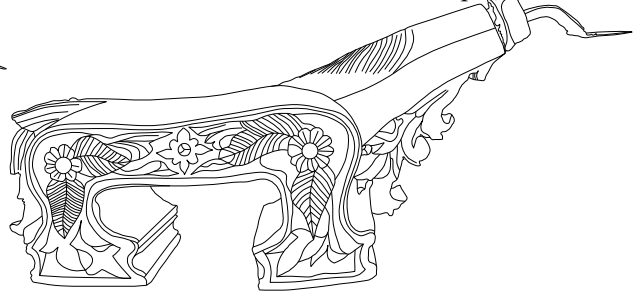

Source 4: Selangor State Museum 


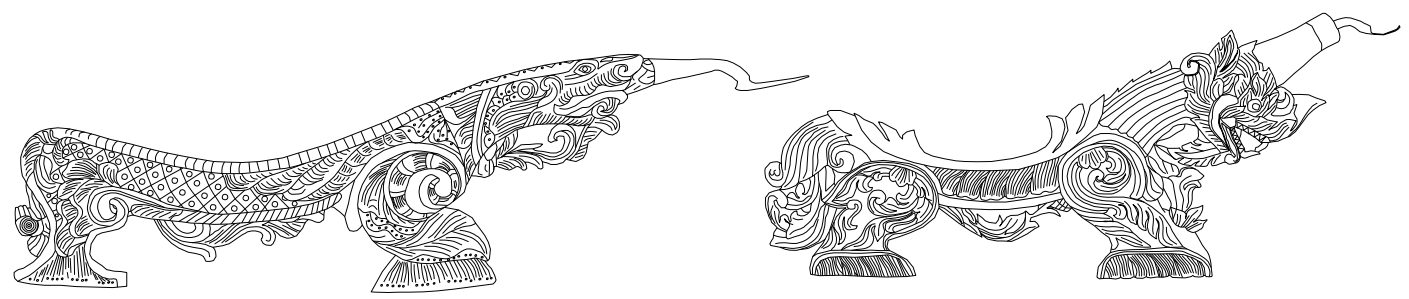

Source 6: Terengganu State Museum

Source 5: Kelantan State Museum

Figure 3: Variation of ornamental carvings in kukuran body

Illustrated by: Zulkfli bin Md Yusoff

Common source of inspiration for the Malay craftsmen is in nature. Flowers, fruits, and plants were used widely in their carvings. The most commonly carved leaf designs were ketola, janggut keli, ketamguri, bakawali, kedudut, kembek, pucuk rebung, daun pulut, ketumbit, bunga kacang, kiambang, kiambang and others (Farish A. Noor \& Khoo, 2003; Ismail Said, 2004; Zawiyah Baba (ed), 2010). However, the awan larat patterns can be divided into three types; awan larat Melayu, awan larat Jawa or cross pattern and awan larat Jawi (Suhaimi Hussin, 2006). He further that flora carvings using awan larat were ketola, bunga kacang, bunga raya, bunga teratai, bunga cengkih, bunga semantong, bunga kembong, bunga si tampuk manggis, bunga dala, bunga cempaka, bunga telipot, bunga ketam guri, pucuk paku, pepulut, kangkung, jari buaya, kerak nasi and so on.

Thus, the forms and motifs significantly influence the pattern of the carving. Evans (1967) had divided Malay patterns into three classes which were geometrical patterns, patterns derived from plants and flowers, and patterns derived from animals. In additional to that, animism forms of motifs are chosen characteristic of the early sculptures in Malay world (Zulkifli Hanafi, 2000). The Javanese motifs are different from the traditional motifs in Malay Peninsular. The Javanese motifs were namely after their previous empires (Soepratno, 1983). The motifs were Pejajaran, Mataram, Majapahit, and Bali motifs. Then it evolved to the district motifs such Jepara, Madura, Cirebon, Surakarta, Yogyarkata, Perkalongan and Semarangan.

The creation of carving motifs in the selected kukuran are focused on sourses of natural motifs (mostly flora motifs such leaves, stalk, tendrils, fruits and flowers of local plant). However, it is difficult to identify and recognize the flora motifs used as ornamental carvings. The motifs might be imitated, denaturalized, stylized and abstracted due to artistic sense, intuitive and style of the craftsmen. In the art of woodcarving, the preliminary philosophy of beauty is based on the origin source or the beginning of a growth. The term sprout from origin or seed (tumbuh berpunca) symbolized a particular creation. It denoted that craftsmen were influenced by the devotion to the Creator of the Universe and concept of Divine Essence (Zat). Preliminary study showed that most of the carving motifs can be referred to the concept of Jamal (beauty) and Jalal (magnificent) as seen in Figure 1. The carving techniques used in above kukuran were mostly relief carving techniques.

Apart from this, it is difficult to identify and recognize the flora motifs used as ornamental carvings. The motifs were stylized due to artistic sense, intuitive and style of the craftsmen. However the further investigation will be required in order to find its origin. As 
Sherpard (1978) noticed that the motifs in Malay decorative designs were not necessary came from Malay origin. He believed that some of the motifs have been adapted and modified for century. Therefore, the underlying concept of ornamental carvings in kukuran adhered to the concept of Islami art but not all of its visual forms are clearly revealed and manifested in other aspects of Malay art form and custom. In a way, this paper offers some understanding and insight into the Malay concept of beauty as well as in the spirit of Islam. Nevertheless, evidence of pre-Islamic cultural can be seen in the kukuran ornamental carvings. In short, the formalistic aspects of the kukuran ornamental carvings are always supported by the Islamic iconolography as a whole.

\subsection{CONCLUSION}

The ornamental carvings in kukuran have its own identity and value that reflect the form and soul of the Malay craftsmen. Each and every one of these ornamental carvings has its own unique compositions and significant to the Malay concept of beauty. The Islamic understanding and Malay carvings philosophy have also influences the development of the kukuran. With the coming of Islam, the ornamental carvings in kukuran had manifested the teaching of Islam by achieving to the do's and don't in any creative endevour. Based on the analysis of the under study kukuran, it shows that the Islamic influence has contributed to their design. However the shapes of these kukuran are more semi-figurative but the used of motifs as decorative elements are more toward nature.

Consequently, ornamental carvings in kukuran manifest the level of creativity of it craftmen by adopting nature into its design. The beauty, uniqueness and harmony of the carvings have formed a dynamic ensemble. It is an abstract form of nature. It comprises of imitation, denaturalization, stylization and abstraction processes. The nature sources were form simply following the teaching of Islam. As a result, the ornamental carvings used in kukuran shows clearly distinct from other architecture components. This difference can be seen in the use of motifs, arrangement, and pattern of woodcarving. The ornamental carving in kukuran under study shows clearly part of Malay woodcarving philosophy.

\section{REFERENCES}

Abdul Halim Nasir (1987). Traditional Malay Woodcarving. Kuala Lumpur: Dewan Bahasa dan Pustaka.

Abdullah Mohamed (1980). "Falsafah dan Pemikiran Orang-Orang Melayu: Hubungan dengan Illahi dan

Kesenian”. Kementerian Kebudayaan, Belia dan Sukan, Malaysia.

Abdullah Mohamed (Nakula). (2006). "Islam Sebagai Teras Falsafah Keindahan Melayu dengan Tumpuan Khas kepada Seni Bina dan Seni Ukir di Kelantan”. In Monograf Perbadanan Muzium Negeri Kelantan; Warisan Kelantan XXV. Kuala Lumpur: United Selangor Press Sdn Bhd. pp. 32-34.

Balai Seni Lukis Negara. (1993). Form \& Soul Catalogue. Balai Seni Lukis Negara. Kuala Lumpur. 
Che Husna Azhari. (2011). “Artifak Sains dan Teknologi Alam Melayu”. Universiti Kebangsaan Malaysia.

Evans H. N. I. (1967). "Some Malay Patterns and Designs”. Journal of Federated Malay States Museums, Vol XII Part 7. pp.163-167.

Farish A. Noor. \& Khoo, E. (2003). Spirit of Wood: The Art of Malay Woodcarving. Singapore: Periplus Editions (HK) Ltd.

Haziyah Hussin, Zawiyah baba, Aminuddin Hassan, Aishah@Esah Haji Mohamed (2012).

The Philosophy in the Creation of Traditional Malay Carving Motifs in Peninsular Malaysia. In GEOGRAFIA Online ${ }^{T M}$ Malaysia Journal of Society and Space. 8 issue. ISSN 2180-2491. p., 88-95.

Ismail Said. (2004). Beauty of Material: Selecting Timber Species for Malay Woodcarving. Journal Alam Bina Issue 06 June 2004, 45-54.

Jabatan Muzium dan Antikuiti. (2005). "Kayu dan Semangat: Pameran Alam Ukiran Kayu Melayu Tradisi Kelantan, Terengganu dan Pattani”. Kuala Lumpur: Jabatan Muzium dan Antikuiti.

Mohamed Najib Ahmad Dawa. (2009)."Transformation Tradition for Contemporary Context”. Balai Seni Lukis Negara

Mohd Suhaimi Tohid. (2006). Ethical Values in Malay Woodcarving: A Case Study of Wan mustaffa Wan Su's Work. M.A Thesis. Universiti Teknologi MARA, Shah Alam, Selangor.

Rosnawati Othman. (2005). The Language of Langkasuka Motif, Indonesia and the Malay World. 33 (96), pp. 97-111

Seminar Report. Seminar Warisan Seni Bangsa: Bicara Warisan Khazanah Jiwa, Shah Alam Selangor. Malaysia - $9^{\text {th }}$ April 2005.

Sherpard, M. (1978). Living crafts of Malaysia. Singapore: Times Book International.

Siti Zainon Ismail. (1986). “Reka Bentuk Kraftangan Melayu Tradisi”. Kuala Lumpur: Dewan Bahasa dan Pustaka.

Siti Zainon Ismail. (1997). The Traditional Malay Handicraft Design. Kuala Lumpur: Dewan Bahasa dan Pustaka.

Soepratno, B. A (1983). “Ornamen Ukiran Kayu Traditional Jawa”. Semarang, Indonesia. pp.,18-23.

Suhaimi Hussin. (2006). "Perkembangan Seni Ukiran Kayu di Kelantan", In Monograf Perbadanan Muzium Negeri Kelantan; Warisan Kelantan XXV”. Kuala Lumpur: United Selangor Press Sdn Bhd. pp., 146-150.

Syed Ahmad Jamal. (1994). Form and Soul. Kuala Lumpur: Dewan Bahasa dan Pustaka.

Wan Hashim Wan Teh. (1996). Malay Handicraft Industries: Origin and Development. Kuala Lumpur: Dewan Bahasa dan Pustaka.p.,80

Zakaria Ali (1989). "Seni dan Seniman”. Kuala Lumpur: Dewan Bahasa dan Pustaka.

Zawiyah Baba. (ed.) (2010). "Warisan Seni Ukir Kayu Melayu: Legacy of the Art of Malay Woodcarving”. Institut Alam dan Tamadun Melayu. Universiti Kebangsaan Malaysia, Bangi, Selangor.

Zulkfli Md Yusoff and Dzull Haimi Md Zain. (2012). The Aesthetic Morphology of Malay Kukuran. In Proceding of $2^{\text {nd }}$ USM-PSU International Conference on Art \& Sciences '12. Penang: Universiti Sains Malaysia. 
SHS Web of Conferences

Zulkifli Hanafi (2000). “Pola-Pola Hiasan di dalam Bangunan Traditional Melayu”. Kuala Lumpur: Dewan Bahasa dan Pustaka. 